\title{
INCIDENCE OF COLOUR BLINDNESS IN INDIANS*
}

\author{
BY \\ KRISHNA SWAMI MEHRA \\ College of Medical Sciences, Benares (India)
}

NORMAL colour vision is of great importance for workers in many occupations, and those with defective colour vision should not be employed on tasks requiring good colour discrimination.

Colour blindness is usually a congenital defect. François and Verriest (1957a) state that colour vision defects in man are due to accidental mutations rather than to "atavism". Acquired colour blindness has been reported by François and Verriest (1957b) in cases of aphakia, senile macular degeneration, progressive myopia, retinal detachment, and chorio-retinitis.

Statistics on the incidence of colour blindness in the general population are few. François, Verriest, Mortier, and Vanderdonck (1957) examined 1,243 young male students and found that 128 (8 per cent.) were colour blind. Montauffier, Riu, Camo, and Hebert (1958) found that 7 per cent. of 517 navy personnel were colour blind. In the series of 500 people Belcher, Greenshields, and Wrights (1958) found 38 (7.6 per cent.) colour blind.

The incidence of colour blindness in races other than European has not been widely studied. Rivers (1901) investigated a local population in Upper Egypt, and also carried out a survey in Papunas and Todas (Rivers, 1904) where 10 per cent. of the population was colour blind. Geddes (1946) examined 148 Fijian natives and found $12(8 \cdot 1$ per cent.) colour blind. Simon (1951) examined 537 Buganda Africans and found only 1.86 per cent. to be colour blind.

Mann and Turner (1956) found that 1.9 per cent. of male and 0.031 per cent. of female aboriginals were colour blind, but the figures for white Australians were higher -7.3 per cent. for males and 0.61 per cent. for females.

Anomalies of colour vision in Japanese children have been reported by Nakajima, Ichikawa, Nakagawa, Majima, and Watanabe (1960), who examined 3,033 children, of whom 81 (77 males and 4 females) were defective.

These previous studies are summarized in Table I (overleaf).

No assessment of the incidence of colour blindness in an Indian population has so far been made.

\section{Material and Methods}

This survey was carried out in the city of Benares in the province of Uttar Pradesh. According to the Hindu religion Benares is a holy city, so the population includes people from various parts of India-Bengal, Madras, Gujrat, etc. 
TABLE I

FINDINGS IN PREVIOUS SURVEYS

\begin{tabular}{|c|c|c|c|c|c|c|c|}
\hline \multirow{3}{*}{ Author } & \multirow{3}{*}{ Date } & \multirow{3}{*}{ Population } & \multirow{3}{*}{$\begin{array}{c}\text { Total } \\
\text { Examined }\end{array}$} & \multicolumn{4}{|c|}{ Colour Blind } \\
\hline & & & & \multicolumn{2}{|c|}{ No. } & \multicolumn{2}{|c|}{ Per cent. } \\
\hline & & & & Male & Female & Male & Female \\
\hline François and others & 1957 & $\begin{array}{l}\text { Belgian male } \\
\text { students }\end{array}$ & 1,243 & 128 & - & $8 \cdot 0$ & - \\
\hline $\begin{array}{l}\text { Montauffier and } \\
\text { others }\end{array}$ & 1958 & Naval personnel & 517 & \multicolumn{2}{|c|}{ Not stated } & $7 \cdot 0$ & - \\
\hline Belcher and others & 1958 & British & 500 & \multicolumn{2}{|c|}{38} & \multicolumn{2}{|r|}{$7 \cdot 6$} \\
\hline Rivers & 1904 & $\begin{array}{l}\text { Papunas and } \\
\text { Todas }\end{array}$ & - & \multicolumn{2}{|c|}{-} & \multicolumn{2}{|c|}{$10 \cdot 0$} \\
\hline Geddes & 1946 & Fiji & 148 & \multicolumn{2}{|c|}{ - } & \multicolumn{2}{|r|}{$8 \cdot 1$} \\
\hline Simon & 1951 & Buganda & 537 & \multicolumn{2}{|c|}{ - } & \multicolumn{2}{|r|}{1.86} \\
\hline Mann and Turner & 1956 & $\begin{array}{l}\text { Aborigines } \\
\text { White Australians }\end{array}$ & - & \multicolumn{2}{|r|}{-} & $\begin{array}{l}1.9 \\
7 \cdot 3\end{array}$ & $\begin{array}{l}0.031 \\
0.61\end{array}$ \\
\hline Nakajima and others & 1960 & Japanese & 3,033 & 77 & 4 & & \\
\hline
\end{tabular}

All the patients attending the Ophthalmic out-patients department, excluding those with detachment of the retina, high myopia, macular degeneration, marked lenticular changes, and chorio-retinitis, were examined for colour vision on the Ishihara chart.

Illiterate patients were asked to trace the figures with the finger. Some students from Benares University who had no eye disease were also examined, making a total of 1,500 persons whose ages ranged from 7 to 50 years.

\section{Results}

A cross-section of the population of the city of Benares (India) was tested for colour vision. Out of the 1,500 persons examined, there were 42 colour blind ( 2.8 per cent.) -3.6 per cent. for males and 1.04 per cent. for females (Table II).

TABLE II

INCIDENCE OF COLOUR BLINDNESS IN INDIANS

\begin{tabular}{c|c|c|c}
\hline \multirow{2}{*}{ Sex } & \multirow{2}{*}{ Number of Patients } & \multicolumn{2}{|c}{ Colour Blind } \\
\cline { 2 - 3 } & & Number & Per cent. \\
\hline Male & 1,023 & 37 & 3.69 \\
\hline Female & 477 & 5 & 1.044 \\
\hline
\end{tabular}


Of these colour blind persons only six had attended the ophthalmic outpatients department with a complaint of defective colour vision.

I am grateful to the Principal of the College of Medical Sciences, Benares, for permitting me to publish this paper, and to Dr. B. B. Khare for helping me in this project.

\section{REFERENCES}

Belcher, S. J., Greenshields, K. W., and Wright, W. D. (1958). Brit. J. Ophthal., 42, 355.

FrançoIs, J., and Verriest, G. (1957a). Ann. Oculist. (Paris), 190, 633. (1957b). Ibid., 190, 812.

, MORTIER, V., and VANDERDONCK, R. (1957). Ibid., 190, 5.

GEDDES, W. R. (1946-47). Brit. J. Psychol., 37, 30.

MANN, I., and TURNER, C. (1956). Amer. J. Ophthal., 41, 797.

MONTAUFFIER, R., RIU, R., CAMO, R., and HeBERT, M. (1958). Ann. Oculist. (Paris), 191, 420.

RIVERS, W. H. R. (1901), J. Roy. anthropological Inst., 31, 239.

(1904-5). Brit. J. Psychol., 1, 321.

Simon, K. (1951). E. Afr. med. J., 28, 75. 